DOI 10.1515/linpo-2016-0005

\title{
Agreement in Modern Standard Arabic constructions with cardinal numerals over ten
}

\author{
Marcin Michalski \\ Institute of Linguistics, Adam Mickiewicz University in Poznań \\ e-mail: mmich@amu.edu.pl
}

\begin{abstract}
In Modern Standard Arabic constructions with cardinal numerals over ten in which the noun denoting the counted object follows the numeral, e.g. al-hamsūna ğundiyyan 'the fifty soldiers' (as opposed to al-ğunüdu l-hamsüna 'idem'), the noun is indefinite singular. When a property of the object counted is to be expressed by means of an attribute: an adjective, participle, or a relative clause, it agrees with the noun in gender, but agreement in the three remaining categories, i.e. number, case and definiteness, may be distributed between the noun and the numeral. The present study analyzes examples of such constructions found in contemporary journalistic texts. Four agreement configurations are distinguished, out of which three were described by Classical Arabic grammarians, while one is non-classical. In some instances, due to the syncretism of declension forms, agreement in case is indeterminate. The analysis of the examples shows that apart from variation in agreement that can be observed with some types of the qualifier, the choice of a particular agreement configuration depends on phraseology and/or the lexico-syntactic properties of the qualifier: whether it is a proper adjective, a nisba adjective, a participle, or a relative clause.
\end{abstract}

Keywords: Modern Standard Arabic, agreement, semantic agreement, syntactic agreement, Arabic cardinal numeral, numeral construction, numeral syntagm.

\section{Introductory remarks}

In Modern Standard Arabic (hereafter MSA), cardinal numerals between 11 and 99 on one hand and one hundred and its multiples on the other constitute separate categories from the point of view of syntax. According to classical rules, the numeral is the qualified (modified) constituent while the noun denoting the counted object is the qualifying (modifying) constituent (qualifier). The noun is governed for case by the numeral. The numeral's ability to govern nouns for case is a feature shared with nouns. (In fact, the numeral cannot be considered a separate part of speech in MSA on grounds other than semantic ones.) Another feature that is shared by this numeral with the noun and that is of interest to us here is that in this classical type of construction, when a property of the object counted is to be expressed by means of an attribute, i.e. an adjective (understood as a non-participial positive ${ }^{1}$ ), partici-

${ }^{1}$ The elative, excluded from our present considerations, deserves a separate study in this respect. 
ple, or a clause, the numeral may function as the controller of this attribute as far as agreement in three categories, i.e. number, case and definiteness, is concerned. Despite the fact that the issue of Standard Arabic numerals in general has been frequently discussed, both in classical and modern descriptions, the agreement relationships in question have not been duly described. Hasan, author of a well-known grammar of Arabic, remarks that the problem was not presented clearly by classical grammarians (Hasan [n.d.]: IV, 530, fn. 1.). Modern descriptions of this language are not satisfactory, as well as rules included in school grammars and university course books.

The type of construction we will be concerned with will be referred to as classical in this paper, as it is the one described by classical and classicizing Arabic grammarians (as opposed to another, innovative one, termed adjectival). First, the classical construction and its descriptions in Western and Arabic grammars of Classical Arabic and MSA will be presented. Then, agreement configurations used with this construction involving adjectival, participial and clausal qualification will be identified and illustrated with examples from real usage (journalistic texts) ${ }^{2}$. Finally, an attempt will be made to identify factors (conditions) that determine the choice of particular agreement configurations.

\section{The syntax of the classical construction and attributive construction}

In the classical construction, the noun denoting the counted object, termed in Arabic tamyīz al- 'adad 'specification of the numeral' (al-Ġalāyīnī 2010 [1912]: 577), is singular and indefinite; it follows the numeral immediately and is governed by it for case, which is the accusative with the numerals from 11 to 99 and the genitive with one hundred and its multiples $^{3}$. The classical construction is thus one based on government, the numeral being the governor and the noun the governee. The feature of definiteness is marked on the numeral (by means of the definite article $a l^{-4}$ ). Examples (1) and (2) show a numeral from the range 11-99:

$$
\begin{aligned}
& \text { خمسون ولدا } \\
& \text { hamsūna walad-a-n } \\
& \text { fifty.NOM boy(M).SG-ACC-INDF }{ }^{5} \\
& \text { 'fifty boys' }
\end{aligned}
$$

2 The texts from which examples are taken are online versions of Arabic newspapers and media sites: al-'Ahrām (Cairo), BBC Arabic (London), CNN Arabic (Dubai), al-Dustūr ${ }_{A}$ (Amman), al-Dustūr ${ }_{C}$ (Cairo), al-Ğazīra (Doha), al-Ǧazīra ${ }_{R}$ (Riyadh), al-Ḥayāt (London), al-Mașrī al-Yawm (Cairo), al-Mustaqbal (Beirut), al-Nahār (Beirut), al-Riyạ̣̄ (Riyadh), al-Šarq al-'Awsaț (London), and Tišrīn (Damascus). Website addresses are given in endnotes. The examples have been found through targeted queries performed with the use of the Google search engine.

${ }^{3}$ If in a compound numeral the last component is a decade, hundred or thousand, it is this last component that governs the noun for case.

${ }^{4}$ The transcription used in this paper reflects the fact that the vowel of the article is elided after words ending in vowels and, in most cases, changes to $i$ after words ending in consonants. The assimilation of $l$ to the so-called 'sun letters' is not indicated.

${ }^{5}$ Only units that are relevant for the present considerations are fully glossed. Since the relevant nouns are all personal, the feature 'personal' is not marked in the glossing line. 
(2)

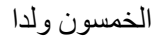

al-ḩamsūna

walad-a- $n$

DEF-fifty.NOM

'the fifty boys'

boy(M).SG -ACC-INDF

In examples (3) and (4), the category of one hundred and its multiples is exemplified:

(3) مئة ولد

mi'at-u walad-i-n

hundred-NOM boy(M).SG-GEN-INDF

'a hundred boys'

(4) المئة ولد

al-mi'at-u walad-i-n

DEF-hundred-NOM boy(M).SG-GEN-INDF

'the hundred boys' ${ }^{\prime}$

By contrast, in the attributive construction, the numeral functions as an attribute (hence the name) of a plural noun designating the counted object and agrees with it in case and definiteness (plurality being an inherent feature of the numeral, while its gender appears to be non-specified). Thus, the attributive construction is one based on agreement, the noun being the controller and the numeral the target. Usually, it is used with definite nouns ${ }^{7}$. It is exemplified in (5) and (6):

$$
\begin{array}{ll}
\text { الأو لاد الخمسون } & \\
\text { al-'awlād-u } & \text { l-hamsūna } \\
\text { DEF-boy(M).PL-NOM } & \text { DEF-fifty.NOM } \\
\text { 'the fifty boys' } &
\end{array}
$$

(6) الأولاد المئة

$$
\begin{array}{ll}
\text { al-'awlād-u } & l \text {-mi'at-u } \\
\text { DEF-boy(M).PL-NOM } & \text { DEF-hundred-NOM }
\end{array}
$$

'the hundred boys'

Classical and classicizing grammars written by Arab authors seem not to know the attributive construction for this range of numerals ${ }^{8}$. According to them, only cardinal numerals up

${ }^{6}$ This type of construction, which can be found in some classical texts although classical rules prohibit the use of the definite article on the first term of genitive constructions, was approved by the Cairo Academy of the Arabic Language in 1973 (al-'Adnānī 1989 [1984]: 434, nº 1257).

7 The following example with an indefinite noun given by Būhudūd (1987:252) is rather exceptional:

عندي كتب ثلاثون

$\begin{array}{lll}\text { 'ind-i } & k \text { kutub-u-n } & \underline{\text { talät} t u ̄ n a ~} \\ \text { at-1SG } & \text { book.PL-NOM-INDF } & \text { thirty.NOM }\end{array}$

'I have thirty books'.

${ }^{8}$ Examples showing that the attributive construction was used in this way in Classical Arabic are adduced by Reckendorf (1921: 207), who characterizes them as "weit seltener" (much less frequent). As far as diachrony is concerned, this construction might have developed by way of analogy with the numerals from 3 to 9 (e.g. al-riğa 
to 10 can be used attributively, while decades from 20 onwards, hundreds, thousands, etc., when used attributively, combine with singular nouns and have an ordinal, not cardinal meaning, e.g.

$$
\begin{array}{ll}
\text { الولد الخمسون } & \\
\text { al-walad-u } & \text { l-ḩamsūna } \\
\text { DEF-boy(M)-NOM } & \text { DEF-fifty.NOM } \\
\text { 'the fiftieth boy' } &
\end{array}
$$

In modern Western descriptions of Classical and/or Modern Standard Arabic, rules for combining nouns with numerals over ten are presented in a very heterogeneous manner, especially as far as definite numerals are concerned. Some authors do not deal with the problem of definite numerals over ten at all, e.g. Alosh (2005: 288-289); Haywood \& Nahmad (1993 [1962]: 307-308). In other works, only the classical construction is given, e.g. Wright (1962 [1862]: II, 245); Fischer (1972: 73), and Grande (1963: 357-358 and 362) for classical Arabic; Buckley (2004: 916-922) and Holes (2004 [1995]: 214-215) for Modern Arabic. In Schulz et al. (2000: 128), by contrast, the attributive construction is introduced before the classical one, while a note in this textbook says that classical construction "is also frequently found". Sometimes the attributive construction is only hinted at; for instance, Cantarino observes that "it does not seem to be frequently used" (1974-75: II, 372), Badawi et al. only mention one example of this construction (2004: 273), Corriente gives two instances thereof with hundreds (2002 [1980]: 133-134), whereas El-Ayoubi et al. adduce relevant examples (with "16" and "22") together with numerals from 3 to 10, without indicating any difference between these groups (2001: 363-365). Finally, there are descriptions of MSA in which only the attributive construction is presented: Abu-Chacra (2007: 264) and Ryding (2005: 341).

\section{Agreement in the attributive construction}

As far as agreement in attributive constructions is concerned, the attribute, regardless of its lexico-syntactic category, agrees in number, gender, case (not applicable for relative clauses) and definiteness with the noun. Since the noun is always plural, the attribute is always plural too, as the following examples show for each of these categories, respectively:

(8) ادانت المحكمة المتهمين العشرين الآخرين [al-Šarq al-'Awsaț']

\begin{tabular}{|c|c|c|c|}
\hline min $\quad$ al-šu'arā'-i & l-talātīina & l-qādim-īna & li-l-mušārakat-i \\
\hline
\end{tabular}

$\begin{array}{lllll}\text { 'adānat } & \text { il-mahkamat-u } & \text { l-muttaham-īna } & l \text {-'išrina } & l \text {-'āhar-īna } \\ \text { condemned } & \text { DEF-court-NOM } & \text { DEF-defendant(M)-PL.ACC } & \text { DEF-twenty.ACC } & \text { DEF-other-M.PL.ACC }\end{array}$

'the court condemned the twenty other defendants'

[al-Hayāāt ${ }^{\mathrm{II}}$ من الشعر اء الثلاثين القادمين للمشاركة

'out of the thirty poets coming for the participation'

lu l-hamsatu 'the five men'), which can be used attributively according to the classical rules, especially with definite nouns. 
(10)

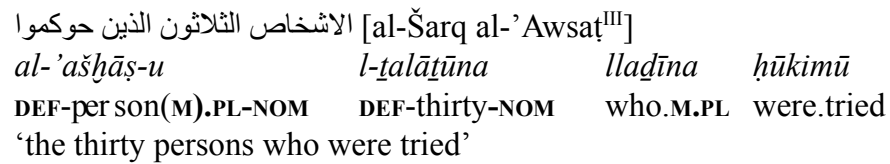

The agreement relationships in attributive constructions might seem rather uninteresting from the morphological or syntactic point of view. For the users, however, this uninterestingness is an advantage because it eliminates uncertainty as to what the qualifier shoud be agreeing with. Perhaps it is the fact that there is only one potential agreement controller in the attributive construction that accounts for its origin and spread.

\section{Agreement in the classical construction in previous descriptions}

In the classical construction, by contrast, the issue of the agreement of the qualifier is complex because the attribute may agree, with respect to particular categories, either with the numeral or the noun. A satisfying presentation of this issue cannot be found in classical or modern descriptions of Classical Arabic or MSA. If the problem is raised, the discussion is usually limited to agreement in number, and not exhaustive, while the question of agreement in the remaining categories is left aside. We will start our discussion by recapitulating what modern authors have written as regards this issue in MSA and later on turn to the classical descriptions. The present analysis will be limited to constructions with masculine personal nouns because it is in units showing these morphological features where the MSA agreement relationships are best visible, at least in script.

Modern didactic descriptions written by Arab authors consulted for the needs of this study (al-Daḥdāh 1989 [1981], 'Īd 1982, and al-Ǧārim \& 'Amīn [n.d.], III) do not discuss the problem of adjectival or clausal qualification in such constructions at all. The authors of western descriptions of Classical Arabic, if they devote attention to this issue (Wright 1962 [1862]: II, 238; Reckendorf 1921: 206), follow the classical grammarians but, unfortunately, give only examples with non-personal nouns. Neither Arab nor Western authors dealing with Classical Arabic seem to be concerned with the question of the lexico-morphological category to which a given qualifier belongs, i.e. if it is an adjective, a participle or a relative clause.

In Western descriptions of MSA, if the question of agreement in the classical construction is raised at all, the discussion is limited to agreement in number, of which two types are distinguished: grammatical agreement (with the tamyizz noun), termed by some authors syntactic agreement, and semantic agreement (with the numeral), termed by some authors logical agreement or agreement ad sensum (cf. Corbett 2006: 155). However, the problem is not explored exhaustively or conclusively. Thus, according to Cantarino, only semantic agreement occurs in such constructions ("the agreement will be plural if the idea expressed by the numeral is a plural", 1974-75: II, 385), however, his examples involve only qualifiers that are participles or relative clauses, which will turn out to be of importance. Badawi et al. (2004: $105)$ write that the adjective (they also use an example with a participle) "generally agrees with the grammatical form of the noun, not its logical number", but in the Chapter "Number and gender concord" (p. 270) they add that agreement of adjectives can also be semantic 
("logical"). Buckley claims that agreement in such constructions is grammatical rather than semantic: "Pronouns, adjectives and verbs agree in gender and number (and case - with adjectives) with the numbered noun (...) rather than with the number (...)" (2004: 929) but further on he adds that "[i]f the idea of the number is plural (i.e. more than two), agreement with the numbered noun is usually also plural, even when the noun is in the singular" ( $p$. 930); his examples, however, are not very illustrative to this point. According to Corriente (2002 [1980]: 132), plural agreement is always allowed in such constructions. In the example he adduces, 'arba 'ūna rağulan mu'minina 'forty believing men', the attribute agrees in number with the numeral, but in case with the noun, which, let us add, is not the most frequent usage in MSA. Some insights about the type of agreement being dependent on the lexico-morphological category of the qualifier have been made by Esseesy (2000) and El-Ayoubi et al. (2001), even though these authors center their attention on agreement in number. Esseesy, who bases his considerations on examples taken from the Qur'ān and Cantarino, observes that "the modifying adjective (...) agrees with the quantified noun (...) by taking the singular indefinite form" (2000: 269-70) but for definite relative clasues, he notes that their relative pronoun agrees in number with the numeral (2000: 278). According to El-Ayoubi et al. (2001: 359-60), adjectival attributes agree grammatically but also, less frequently, semantically, while other modifiers, such as relative clauses, show semantic agreement (2001: 359).

A more complete description can be found in works of classical and classicizing Arab grammarians. The issue of agreement did interest classical grammarians, who, however, were concerned mostly with agreement in number and case and used only adjectival attributes in their examples. For instance, al-Suyūṭ̂̄ in his Ham ' al-hawāmi ' (quoted by Hasan [n.d.]: IV, 531, fn. $1 \rightarrow$ ) adduces examples showing several possible configurations of agreement in case and number. Apart from one, which seems rather rare and is not used in MSA9, the same configurations are given in al-Ġalāyīn̄̄'s popular compendium (2010 [1912]: 577). Leaving aside constructions with nouns other than masculine personal, these configurations can be reduced to three.

In Configuration 1, the qualifier agrees in case and number with the noun, i.e. agrees with the grammatical form (lafz) of the tamyiz noun (grammatical agreement). The qualifier is thus singular, in the accusative with numerals from 11 to 90 and in the genitive with one hundred and its multiples:

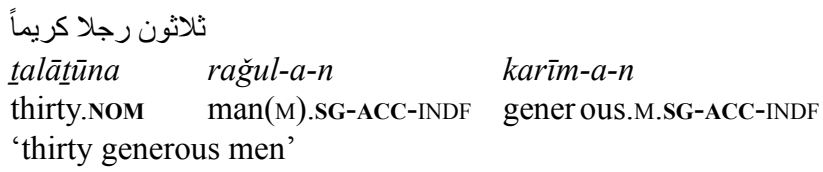

${ }^{9}$ This configuration, in which the qualifier agrees in number with the noun and in case with the numeral, is exemplified as follows:

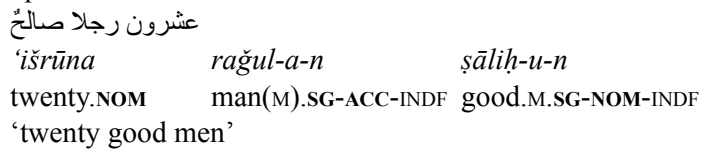


(12)

$\begin{array}{lll} & \\ \text { mi'at-u } & \text { rağul-i-n } & \text { karīm-i- } n \\ \text { hundred-NOM } & \text { man(M).SG-GEN-INDF } & \text { gener ous.M.SG-GEN-INDF } \\ \text { 'one hundred generous men' } & \end{array}$

In the two remaining configurations, 2 and 3, the qualifier is plural. As al-Ġalāyīn̄ explains, this plural form can be interpreted as reflecting the sense of the tamyiz noun - because rağulan is used "in the sense of al-riğâl" (fi ma 'na al-riğăl, al-Ġalāyīnī 2010 [1912]: 577) - or as agreeing with the meaning of the numeral, which is inherently plural (semantic agreement $)^{10}$.

In Configuration 2, the qualifier agrees in case and number with the numeral, consequently, it is plural. If the qualifier is an adjective, it may have a 'sound' (i.e. suffixal or external) plural (Subconfiguration 2a), as in (13), or a 'broken' (i.e. internal) plural (Subconfiguration $2 b)^{11}$, as in (14):

$$
\begin{array}{ll}
\text { أربعون رجلا صالحون } & \\
\text { 'arba 'üna rağul-a-n } & \text { șālihh-ūna } \\
\text { forty.NOM man(M).SG-ACC-INDF } & \text { good-M.PL.NOM } \\
\text { 'forty good men' } &
\end{array}
$$

ثلاثون رجلا كر امُم (14)

$$
\begin{array}{lll}
\text { talāțūna } & \text { rağul-a-n } & \text { kirām-u- } n \\
\text { thirty.NOM } & \text { man(M).SG-ACC-INDF } & \text { generous.M.PL-NOM-INDF }
\end{array}
$$

'thirty generous men'

In Configuration 3, the qualifier agrees in case with the noun and in number with the numeral; thus, it is plural. This configuration is restricted to adjectives that have a broken plural:

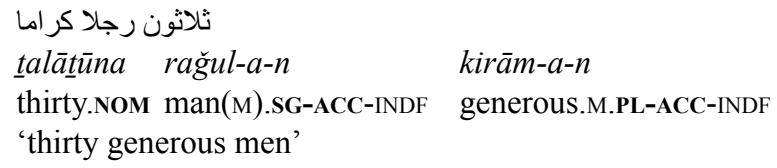

The three configurations of agreement in case and number according to classical rule presented by al-Ġalāyīnī, are represented in Table 1:

${ }^{10}$ Unlike al-Ġalāyīn̄, who does not say which of these two agreement types, grammatical or semantic, is preferable or more frequent, Hasan claims that grammatical agreement (murà' 'àt al-lafz) is more often ([n.d.]: IV, 530, fn. 1).

11 Interestingly, in some editions of al-Ġalāyīnī's book (e.g. 1994: III, 126; 2002: 493), probably due to a misprint, the existence of this quite frequent configuration is not indicated. Configuration 3, a less frequent one, is repeated there instead, which makes this passage rather obscure. 


\begin{tabular}{|c|c|c|c|}
\cline { 2 - 4 } \multicolumn{1}{c|}{} & $\begin{array}{c}\text { Controller of } \\
\text { agreement in number }\end{array}$ & $\begin{array}{c}\text { Controller of } \\
\text { agreement in case }\end{array}$ & Additional information \\
\hline Configuration 1 & noun & noun & syntactic agreement \\
\hline Configuration 2 & numeral & numeral & $\begin{array}{c}\text { semantic agreement; } \\
\text { broken and sound plurals }\end{array}$ \\
\hline Configuration 3 & numeral & noun & $\begin{array}{c}\text { mixed semantic and } \\
\text { syntactic agreement; } \\
\text { broken plurals only }\end{array}$ \\
\hline
\end{tabular}

Table 1. Agreement in number and case according to al-Ġalāyīnī (2010 [1912]: 577)

At this point, it can be added that the qualifier always agrees in gender with the noun, never with the numeral, which does not have an inherent gender. The gender of the numeral, if marked at all (only on those with units), reflects the gender of the noun denoting the counted object.

\section{Agreement configurations}

All of the configurations of agreement in case and number presented above are used in the MSA texts. In what follows, they will be completed by characterizing them with respect to the feature of definiteness. To this aim, examples taken from journalistic texts will be analyzed. They will also serve us for identifying possible other configurations. The choice of examples is intended to reflect the fact that the numeral may be definite or indefinite and that the qualifiers represent various lexico-morphological categories: proper adjectives, nisba adjectives, the adjective 'āhar-, and participles (relative clauses are dealt with in section 5). It is hypothesized that the categorial membership of the qualifier determines, at least to some extent, the choice of an agreement configuration.

It should be observed that not all agreement relationships are easily identifiable in the real-text occurrences of such constructions. While number and gender agreement relationships are easy to identify, agreement in case and determination may be obscure. This will be discussed in more detail in subsequent paragraphs.

Let us now complete the configurations. In Configuration 1, the qualifier agrees in all four categories with the noun denoting the counted object. Thus, it shows full agreement and is always singular, as represented in Table 2 .

\begin{tabular}{|c|c|}
\hline $\begin{array}{c}\text { Agreement } \\
\text { category }\end{array}$ & Controller \\
\cline { 1 - 1 } gender & \\
\cline { 1 - 1 } number & \multirow{2}{*}{ noun } \\
\cline { 1 - 1 } case & \\
\cline { 1 - 1 } definiteness & \\
\hline
\end{tabular}

Table 2. Configuration 1 (full agreement with the noun). 
Below, examples with indefinite numerals are given for qualifiers belonging to particular categories. The use of participles in this configuration is rare.

[al-Dustūr ${ }_{C}{ }^{\text {IV }}$, proper adjective]

bi-talātata 'ašara là 'ib-a-n ğadìd-a-n

with-thirteen.M.GEN player(M).SG-ACC-INDF new.M.SG-ACC-INDF

'with thirteen new players'

[al-Hayāt ${ }^{\mathrm{V}}$, nisba adjective]

'iṭlāq-u sarāh-i išriñna mu'taqal-a-n

release-NOM liberty-GEN twenty.GEN prisoner(M).SG-ACC-INDF political.M.SG-ACC-INDF

'the release of twenty political prisoners'

[al-Ǧazīra ${ }_{D}^{\text {VI }}$, adjective 'āhar-]

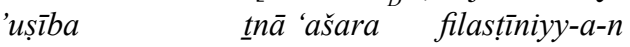

'āhar-a

were.wounded twelve.M.NOM Palestinian(M).SG-ACC-INDF other.M.SG-ACC

'twelve other Palestinians have been wounded'

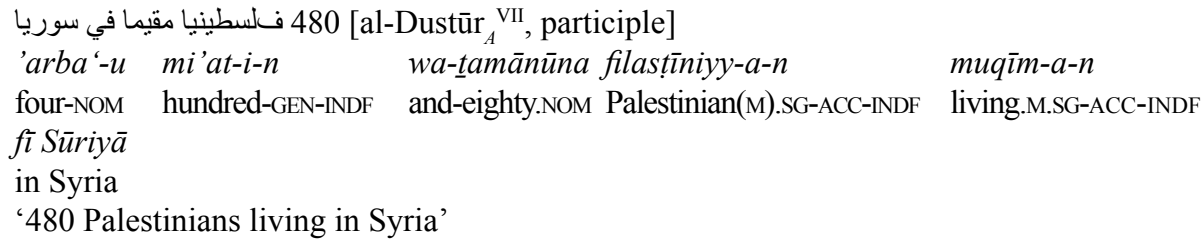

Examples of this configuration with definite numerals are less easy to find. No examples could be found for 'āhar- and participles:

قائمة الـ17 محافظًا جديدًا

qā'imat-u l-sab'ata 'ašara muhāâziz-a-n ğadīd-a-n

list-NOM DEF-seventeen.M.GEN governor(M).SG-ACC-INDF new.M.SG-ACC-INDF

'the list of the seventeen new governors'

(21) عن اختطاف الـ21 صيادًا مصريًا [al-Maṣrī al-YawmX ${ }^{\mathrm{IX}}$, nisba adjective]

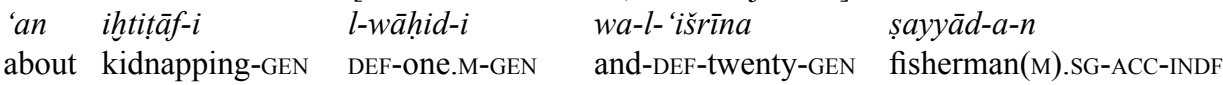

mișriyy- $a-n$

Egyptian.M.SG-ACC-INDF

'about the kidnapping of the 21 Egyptian fishermen'

[CNN Arabic ${ }^{\mathrm{X}}$, adjective 'āhar-]

dūna baqiyyat-i l-sitt-at-i wa-l-'arba'ìna mudān-a-n 'āhar-a

without rest-GEN DEF-SiX-M-GEN and-DEF-forty.GEN convict(M).SG-ACC-INDF other.M.SG-ACC

'to the exclusion of the rest of the 46 other convicts'

In Configurations 2 and 3, which will be discussed in what follows (together with Configuration 4, which will be distinguished subsequently), the qualifier agrees with two control- 
lers simultaneously ${ }^{12}$. A common feature of all these configurations is that it agrees in number with the numeral and consequently is always plural. Therefore, they can be referred to as plural configurations, as opposed to the singular Configuration 1 .

Some remarks must be made here as regards the category of case. All al-Ġalāyīn̄'s (and other authors') examples are given with the numeral in the nominative case, which shows clearly the case agreement relationships. However, in some situations, these relationships may be obscured by the fact that some inflectional endings are normally not written in Arabic script on one hand and by declension syncretism on the other hand. More specifically, case agreement is difficult to determine:

(i) with sound plurals, which have only two declension forms because the genitive and accusative are phonetically (and graphically) syncretic; thus, only the opposition nominative vs. oblique is marked ( ون -üna vs. -ìna);

(ii) with words that have three declension forms but two of them are graphically syncretic; e.g. the nominative ğudud-u-n 'new(M.PL)' and genitive ğudud-i-n are both written جد, جد as opposed to the accusative ğudud-a-n, written

(iii) with words that show graphical syncretism in all three cases, e.g. the nominative 'abriya '- $u$ 'innocent' and genitive and accusative 'abriy $\bar{a}$ '- $a$ are both writen أبرياء; similarly, the three case forms of the masculine plural definite adjective 'new', viz. al-ğudud-u in the

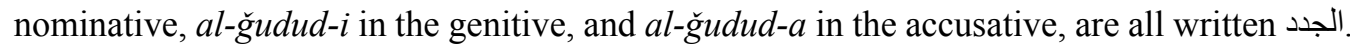

Thus, the choice of proper adjectives that may occur in our examples is rather restricted as those that show unwanted syncretism should be excluded. In what follows, it will be attempted to adduce examples in which the cases can be ascertained. Words the case of which is made obscure by some type of syncretism but can be determined by applying one of the classical rules discussed above will be considered to have an ascertained case.

In addition, it is assumed that the classical rules (indicated by al-Ġalāyīnī) governing the use of cases in constructions with indefinite numerals apply to constructions with definite numerals as well.

We can now take up the discussion of the agreement configurations. In Configuration 2, the qualifier agrees in number, case and definiteness with the numeral. The only feature controlled by the noun is gender, as shown in Table 3 .

\begin{tabular}{|c|c|}
\hline $\begin{array}{c}\text { Agreement } \\
\text { category }\end{array}$ & Controller \\
\cline { 1 - 1 } gender & noun \\
\hline number & \multirow{2}{*}{ numeral } \\
\cline { 1 - 1 } case & \\
\hline definiteness & \\
\hline
\end{tabular}

Table 3. Configuration 2.

${ }^{12}$ See Corbett (2006: 18) for an example of a target that agrees with more than one controller taken from Shona. 
The adjectives that occur in this configuration may have sound or broken plurals. With sound plurals, which have a syncretic form in the genitive and accusative, case agreement is obscured if the numeral is in the genitive or accusative, as in (26), (28) and (30). It is then not clear if the agreement is with the numeral or the noun. However, since it is against classical rules for sound plurals to agree with the noun, such qualifiers will be interpreted as agreeing in case with the numeral. (Notwithstanding, it cannot be excluded that they represent the non-classical Configuration 4, described below and illustrated with examples (45)-(48); therefore, they will be marked with an asterisk).

Below, examples of the use of Configuration 2 with indefinite numerals are given. Those containing nisba adjectives seem rather infrequent.

[al-Dustūr ${ }_{C}$ XI, proper adjective]

ma'a țalātata 'ašara là'ib-a-n

ğudud-i-n $n^{13}$

with thirteen.M.GEN player(M).SG-ACC-INDF new.M.PL-GEN-INDF

'with thirteen new players'

[al-Nahār ${ }^{\mathrm{XII}}$, proper adjective]

ma'a talātat-i mi'at-i-n wa-hamsina muwazzaf-a-n ğudud-i-n

with three.F-GEN hundred-GEN-INDF and-fifty.GEN employee(M).SG-ACC-INDF new.M.PL-GEN-INDF 'with 350 new employees'

[al-Hayāt ${ }^{\mathrm{XIII}}$, nisba adjective]

talaqqā mi'at-u-n wa-'arba'-at-u-n wa-țalātūna lāği'-a-n

received hundred-NOM-INDF and-four-M-NOM-INDF and-thirty.NOM refugee(M).SG-ACC-INDF

sūriyy-ūna l-'ilāğ-a

Syrian-M.PL.NOM DEF-t r eat ment-ACC

'134 Syrian refugees received medical treatment'

[al-Hayāt ${ }^{X I V}$, nisba adjective]*

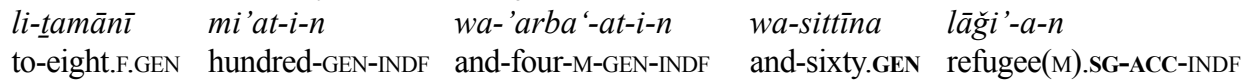

sūriyy-īna

Syrian-M.PL.GEN

'to 864 Syrian refugees'

(27)

[al-Riyāệ ${ }^{\mathrm{Xv}}$, adjective 'āhar-]

'ǐšrūna ğundiyy-a-n 'ăhar-üna

twenty.Nom soldier(M).SG-ACC-INDF other-M.PL.NOM

'twenty other soldiers'

(28) بطاقة 16 ناخباً آخرين [al-Mustaqbal ${ }^{\mathrm{XVI}}$, adjective 'āhar-]*

bițāqat-u sittata 'ašara nāḩib-a-n 'āhar-īna

card-NOM sixteen.M.GEN voter(M).SG-ACC-INDF other-M.PL.GEN

'the cards of sixteen other voters'

13 This configuration corresponds to the classical Subconfiguration $2 b$, therefore, a possible interpretation as the nominative ğududun (written in the same way), which could represent the non-classical Configuration 4 , is rejected. The same concerns (24). 
(29) بينهم 50 شخصا متهمون بـ [al-Ǧazīra XVII, participle] bayna-hum hamsūna šahș-a-n muttaham-ūna biamong-them fifty.NOM person(M).SG-ACC-INDF suspected-M.PL.NOM of 'among them are fifty persones suspected of...'

\begin{tabular}{|c|c|c|}
\hline $\begin{array}{l}\text { li-wāhid-i-n } \quad \text { wa-talātāina } \\
\text { of-one.M-GEN-INDF and-thirt y.GEN }\end{array}$ & $\begin{array}{l}\check{s} a h s-a-n \\
\text { person(M).SG-ACC-INDF }\end{array}$ & $\begin{array}{l}\text { muqūm-īna } \\
\text { living-M.PL.GEN }\end{array}$ \\
\hline
\end{tabular}

Configuration 2 with definite numerals is exemplified in (31)-(35). No examples for proper adjectives are given since such constructions cannot be distinguished from those that represent Configuration 3 (and are listed under Indeterminate Configuration, below). The use with nisba adjectives seems infrequent.

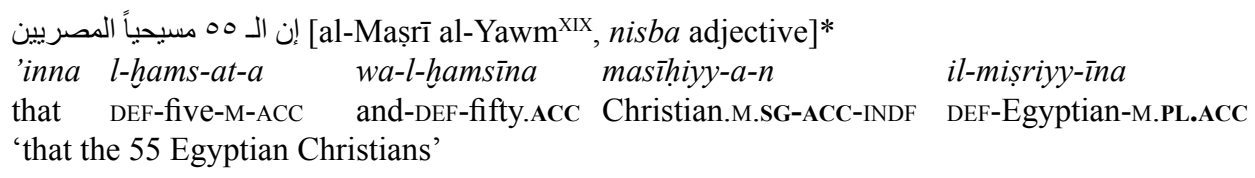
'that the 55 Egyptian Christians'

[al-Šarq al-'Awsaṭ ${ }^{x x}$, adjective 'āhar-]

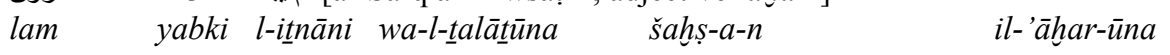
did.not cry DEF-two.M.NOM and-DEF-thirty.NOM person(M).SG-ACC-INDF DEF-other-M.PL.NOM 'the remaining 32 persons did not cry'

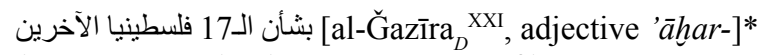

bi-ša'n-i l-sab'ata 'ašara filastīniyy-a-n il-'āhar-īna

in-matter-GEN DEF-seventeen.M.GEN Palestinian(M).SG-ACC-INDF DEF-other-M.PL.GEN

'with respect to the other seventeen Palestinians'

(34) استأنف الـ14 عضواً المتبقون للاجتماع 'al-Hayāt ${ }^{\text {XXII }}$, participle]

ista'nafa l-'arba'ata 'ašara ự̂-a-n ll-mutabaqq-ūna l-iğtimā'-a

resumed DEF-fourt een.M.NOM member(M).SG-ACC-INDF DEF-remaining-M.PL.NOM DEF-meeting-ACC 'the remaining 14 members resumed the meeting'

ضمن الثمانين شخصاً المصابين بـ [al-Riyāệ XXIII, participle]*

dimna l-tamānina šahṣ-a-n il-muṣāb-īna

among DEF-eighty.GEN person(M).SG-ACC-INDF DEF-afflicted-M.PL.GEN

'among the 80 persons afflicted...'

In Configuration 3, the qualifier agrees with the numeral in number and with the noun in case (the accusative), as shown in Table 4. Since only examples with indefinite numerals could be found, it remains unclear if the controller of the agreement in definiteness is the numeral, as in Configuration 2. 


\begin{tabular}{|c|c|}
\hline $\begin{array}{c}\text { Agreement } \\
\text { category }\end{array}$ & Controller \\
\hline gender & noun \\
\hline number & numeral \\
\hline case & noun \\
\hline definiteness & numeral (?) \\
\hline
\end{tabular}

Table 4. Configuration 3.

Below, examples of the use of Configuration 3 with indefinite numerals are given.

[al-Ğazīra ${ }_{R}^{\text {XxIv }}$, proper adjective]

min tamāniyata 'ašara šahș-a-n șumm-a-n wa-bukm-a-n

of eighteen.M.GEN person(M).SG-ACC-INDF deaf.M.PL-ACC-INDF and-mut e.M.PL-ACC-INDF 'of eighteen deaf and mute persons'

[al-Šarq al-'Awsat ${ }^{\mathrm{Xxv}}$, proper adjective]

bi-'ahada 'ašara là'ib-a-n

ğudud-a- $n$

with-eleven.M.GEN player(M).SG-ACC-INDF

neW.M.PL-ACC-INDF

'with eleven new players'

(38)

ضمت 150 شخصا كبار اوصغار [al-Ǧazīra ${ }_{D}^{\text {XxvI }}$, proper adjective]

dammat mi'at-a-n wa-ḩamsina šahș-a-n

kibār-a-n

it.comprised hundred-ACC-INDF and-fifty.ACC per son(M).SG-ACC-INDF adult.M.PL-ACC-INDF

$w a-s i g \bar{a} r-a-n$

and-young.M.PL-ACC-INDF

'it comprised 150 persons, young and old'

[Tišrīn XxVII ， proper adjective]

hawālay tis ìna marīẹ-a-n sig $n$ àr-a-n wa-kibār-a-n

around ninety.GEN patient(M).SG-ACC-INDF young.M.PL-ACC-INDF adult.M.PL-ACC-INDF

'around 90 patients, young and old'

Not many examples for this configuration could be found (as the list of adjectives that fit semantically into journalistic texts and have broken plurals is short), and out of those available, only (36) is unproblematic. Although more examples with جدوu ğududan, used in (37), could be adduced, it cannot be excluded that these forms are misprints for جدوadìdan, a singular belonging to Configuration 1. As for the examples (38) and (39) with șiḡarran and kibāran, it is quite probable that these adjectives are not attributes but non-canonical instances of a circumstantial qualifier $(h \bar{a} l)$ meaning, idiomatically, "both children and adults ${ }^{14}$.

There are, however, examples showing that, contrary to the classical rules, Configuration 3 is used with sound plurals. This configuration is only visible if the numeral is in the nominative

${ }^{14}$ Non-canonical because according to classical rules, a $h \bar{a} l$ must have a definite antecedent, which is not the case in both examples. 
(45)

[al-Šarq al-'Awsat ${ }^{\text {XXXIII }}$, participle]

li-'ilāğ- $i \quad$ išrīna marīọ-a-n mușāb-ūna bi-

for-treatment-GEN twenty.GEN patient(M).SG-ACC-INDF afflicted-M.PL.NOM by

'for the treatment of twenty patients suffering from...'

[al-Ǧazīra ${ }_{R}^{\text {XxxIv }}$, participle]

tamma dabț-u talātīina šahș-a-n

mațlūb-ūna

was.effectuated detention-NOM thirty.GEN person(M).SG-ACC-INDF wanted- M.PL.NOM

'the detention of thirteen wanted persons has been effectuated'

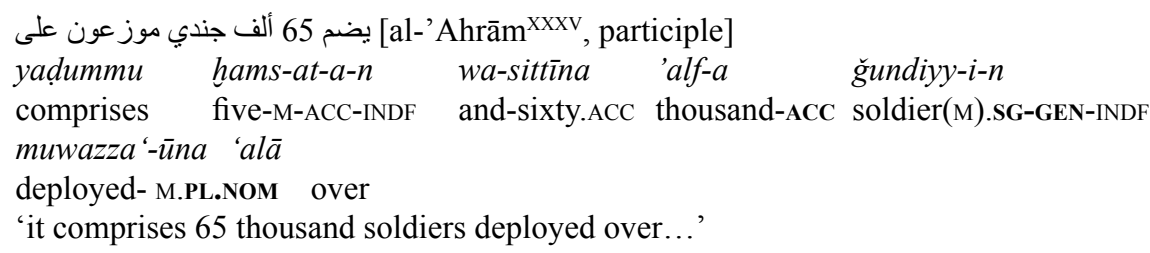

Such expressions, which may be considered instances of hypercorrection, indicate that some users of MSA are uncertain about which case should be used in such situations.

To sum up the above paragraphs, it can be said that the classical rules concerning agreement, as presented by al-Ġalāyīn̄i, are generally observed with the following reservations: Configuration 3 is not frequently used (as few occurrences with indefinite numerals and the absence of examples with definite ones suggest). Innovations can be observed: in Configuration 3 , adjectives with sound plurals are used. Configuration 4 can be identified, possibly reflecting a hypercorrect usage.

\section{Agreement of relative clauses}

The agreement of a relative clause with its controller in gender and number is marked on its subject or verbal predicate if the subject of the relative clause is coreferential with its antecedent, as in (48), or, otherwise, a resumptive pronoun, as in (49). The analysis of our data has shown that relative clauses generally agree with the noun in gender and with the numeral in number and definiteness. The latter feature is marked as the presence or absence of a relative pronoun, as exemplified in (48) and (49), respectively:

$$
\text { [al-Šarq al-'Awsaț }{ }^{\mathrm{XXXVI}]}
$$

wa-min bayn-i l'arba'īna mariệl-a-n illad̄ina kānū yatanāwalūna and-from among-GEN DEF-forty.GEN patient(M).SG-ACC-INDF REL.M.PL were they.take 'out of the forty patients who had been taking...'

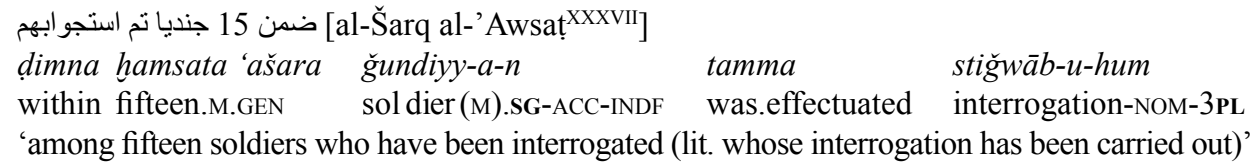


Agreement with respect to case in relative clauses is indeterminate because they do not show morphological properties, e.g. a declinable relative pronoun ${ }^{15}$, that would make it possible to determine their case. The agreement configuration for relative clauses is a plural configuration which can be represented as follows:

\begin{tabular}{|c|c|}
\hline $\begin{array}{c}\text { Agreement } \\
\text { category }\end{array}$ & Controller \\
\hline gender & noun \\
\hline number & numeral \\
\hline case & indeterminate \\
\hline definiteness & numeral \\
\hline
\end{tabular}

Table 5. Agreement configuration for relative clauses.

\section{Two issues related to agreement in definiteness}

Definiteness is marked by means of a definite article with adjectives and participles and by means of a relative pronoun with relative clauses. Indefiniteness, by contrast, is marked by the absence of the definite article or the relative pronoun. Classical sources and contemporary descriptions do not discuss agreement with respect to this category. In examples adduced there (e.g. al-Ġalāyīnı̄'s or Hasan's), constructions with indefinite numerals are used, while agreement relationships as regards definiteness can only be determined when the numeral is definite (otherwise, it cannot be known if the indefiniteness of the qualifier results from its agreeing with the noun or with the numeral). In Configurations 1 and 2, the controller is easy to identify: the noun and the numeral, respectively. For Configurations 3 and 4, however, we have no data, i.e. no instances with definite numerals (extrapolating from Configuration 2 does not seem to be convincing evidence).

Another issue concerns some constructions representing Configuration 2 in which the numeral has no definite article although the qualifier that should agree with it in definiteness is definite. In the following example, the missing articles are given in parentheses:

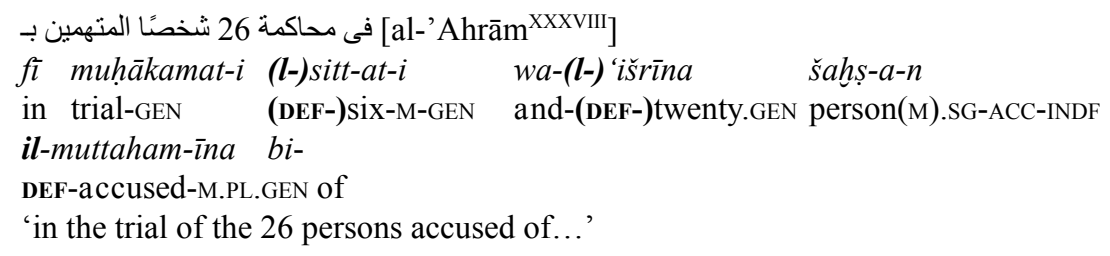

15 Declinable relative pronouns exist in the dual but, understandably, they do not occur in constructions with numerals over ten. 
Such cases are, however, limited to constructions in which the numeral is spelt in numbers ${ }^{16}$. In all constructions with definite qualifiers in which the numeral is written out as words and nearly all in which the numeral is written out as numbers, the numeral does have the article. In cases like (50), the definite article must be supplied by the reader.

\section{An attempt to explain agreement configurations}

The existence of various agreement configurations presented above means that sometimes one semantic content can be coded grammatically in more than one way. However, variation is not always allowed. There are cases in which the choice of a particular agreement configuration is not free. Our analysis allows us to claim that it is determined, at least to a considerable extent, by the lexico-morphological category of the qualifier. The following conclusions can be drawn:

Proper adjectives show strong variation between Configurations 1 and 2 but 1 seems to be preferred, especially with indefinite numerals. In many cases, it is impossible to distinguish Configuration 2 from 3.

With nisba adjectives, Configuration 1 is preferred to Configuration 2.

The adjective 'ăhar- shows variation between Configurations 1 and 2 (less often, non-classically, 3).

With participles, Configuration 2 is generally used (much less often 2 and, hypercorrectly, 4).

Relative clauses are used in a plural configuration.

It is possible that what is, at least partly, responsible for this preference of agreement configurations, (which should be understood in terms of tendencies rather than strict rules), are the degree of inherence of the property in the object denoted by the noun and/or phraseology. Full agreement, i.e. Configuration 1, is preferred with fixed, phraseological expressions composed of a noun and an adjective which would be split if other configurations were used. This accounts, for instance, for the fact that the phrase mu 'taqal siyāsi ' political prisoner' in (17) is used in Configuration 1. We have not found equivalents in other agreement configurations for expressions of this kind. Many adjectives, although not necessarily representing phraseological expressions, designate properties that are inherent, or at least relatively stable, and thus strongly associated with the object. Therefore, they are most frequently used in Configuration 1. This concerns in particular nisba adjectives, for instance, the names

${ }^{16}$ The one occurrence we have come across in which the numeral is written out in words and has no article should arguably be treated as a grammatical or typographical mistake.
[al-Riyāḍ*]
'aktar-u
min mi'at-ay
țālib-i-n
il-ḥāṣil-īna 'alā
more-NOM than hundred-DU.GEN student(M).SG-GEN-INDF
DEF-having.achieved-M.PL.GEN
'more than two hundred students who have achieved...'
* http://www.alriyadh.com/715682 
of nationalities. Other configurations, however, are also possible. They seem to be chosen especially with proper (non-nisba) adjectives denoting accidental features, such as ğadìdun 'new', although more data are needed on this point. Strong variation is displayed by 'āhar-, an adjective that designates a very accidental feature and it is perhaps for this reason that users do not always feel it needs to agree in number with the noun. Participles and relative clauses designate accidental features and this possibly explains why they generally do not show full agreement with the noun.

The distribution of agreement configuration based on the lexico-morphological properties of the qualifiers is well visible when various types of agreement co-occur. Example (51) shows Configuration 1 (filibiniyyan agrees fully with the noun ğundiyyan) co-occurring with Configuration 2 (il-muntaširina agrees agrees in number, case and definiteness with the numeral l-hamsina):

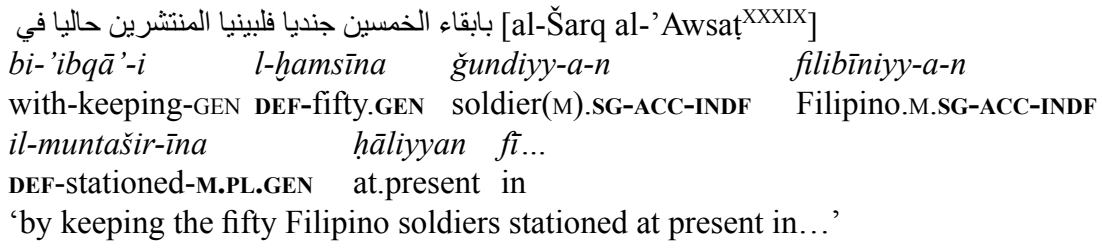

Example (52) shows Configuration 1 ('irāqiyyan agrees fully with the noun mas'ūlan) co-occurring with a plural configuration (the relative clause lladīna tațlubu Wâšintun qatlahum agrees in number and definiteness with the numeral l-itnayni wa-l-hamsina):

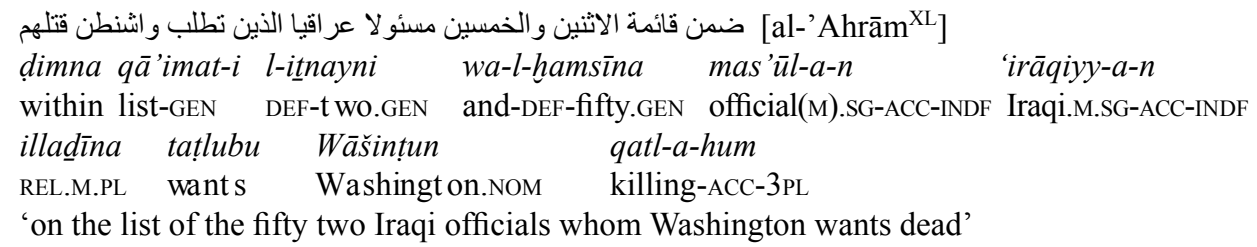

Finally, let us signal an issue that deserves exploration, namely the relationship between particular configurations and the attributive construction. It seems that the fact that in Configuration 1 occurrences of constructions with indefinite numerals were easier to find that those with definite numerals is due to the fact that for the definite meaning the attributive construction is frequently chosen.

\section{Bibliography}

Abu-Chacra Faruk. 2007. Arabic: An Essential Grammar. London-New York: Routledge. al-‘Adnānī Muḥammad. 1989 [1984]. Mu 'ğam al-ag̀lāt al-luǵawiyya al-mu'āṣsira. Bayrūt: Maktabat Lubnān.

Alosh Mahdi. 2005. Using Arabic: A Guide to Contemporary Usage. Cambridge: Cambridge University Press. 
Badawi Elsaid; Carter M.G.; Gully Adrian. 2004. Modern Written Arabic: A Comprehensive Grammar. New York: Routledge.

Buckley Ron. 2004. Modern Literary Arabic: A Reference Grammar. Beirut: Librairie du Liban.

Būhndūd Bahā' al-Dīn. 1987. Al-madhal al-nahwīi: taṭbīq wa-tadrīb fì al-naḥw al- 'arabī. Bayrūt: Al-Mu'assasa al-Ǧāmi'iyya li-1-Dirāsāt wa-1-Našr wa-1-Tawzī'.

Cantarino Vicente. 1974-75. Syntax of Modern Arabic Prose. Vol. 1 (1974), Vols. 2-3 (1975). Bloomington: Indiana University Press.

Corbett Greville G. 2006. Agreement. Cambridge: Cambridge University Press.

Corriente Federico. 2002 [1980]. Gramática árabe. Barcelona: Herder.

al-Daḥdāḥ 'Anțwān. 1989 [1981]. Mu '⿳̆am qawā 'id al-luğa al- 'arabiyya fì ğadāwil wa-lawhāt. Bayrūt: Maktabat Lubnān.

El-Ayoubi Hashem; Fischer Wolfdietrich; Langer Michael. 2001. Syntax der arabischen Schriftsprache der Gegenwart. Teil I, Band 1. Das Nomen und sein Umfeld. Wiesbaden: Reichert.

Esseesy Mohssen. 2000. Morphological and Syntactic Features of Arabic Numerals as Evidence of Their Diachronic Evolution. $\mathrm{PhD}$ diss. Georgetown University.

Fischer Wolfdietrich. 1972. Grammatik des klassischen Arabisch. Wiesbaden: Otto Harrasowitz.

al-Ġalāȳ̄n̄̄ Muștafā. 1994 [1912]. Ǧāmi ‘ al-durūs al- 'arabiyya: Mawsū'a fì țalātat 'ağzā'. ȘaydāBayrūt: al-Maktaba al-'Așriyya, 2 vols.

al-Ġalāyīnī Muștafā. 2002 [1912]. Ǧāmi 'al-durūs al-'arabiyya: Mawsū'a fì țalātat 'ağzā'. ȘaydāBayrūt: al-Maktaba al-'Așriyya.

al-Ġalāyīnī Muștafāă. 2010 [1912]. Ǧāmi ' al-durūs al- 'arabiyya, muḍayyalan bi-bahțay al-balāga wal- 'arụ̣̄. Ed. 'Alī Sulaymān Šabāra. Dimašq-Bayrūt: Mu'assasat al-Risāla Nāširūn.

al-Ğārim 'Alī; 'Amīn Muștafā. [n.d.]. Al-naḥw al-wāọihh fì qawā id al-lugia al- 'arabiyya li-l-marhala al-ibtidā'iyya. Al-Qāhira-Bayrūt: Dār al-Ma'ārif. 3 vols.

Grande B.M. 1963. Kurs arabskoj grammatiki v sravnitel'no-istoričeskom osveščenii. Moskva: Izdatel'stvo Vostočnoj Literatury.

Ḥasan 'Abbās. [n.d.]. Al-naḥw al-wāfì ma 'a rabțihi bi-l-'asālīb al-rafĭ'a wa-l-ḥayāt al-luġawiyya al-mutağaddida. [Cairo]: Dār al-Ma'ārif, 3rd edition, 4 vols.

Haywood J.A.; Nahmad H.M. 1993 [1962]. A New Arabic Grammar of the Written Language. London: Lund Humphries.

Holes Clive. 2004 [1995]. Modern Arabic: Structures, Functions and Varieties. Washington: Georgetown University Press.

'Īd Muḥammad. 1982. Al-naḥw al-mușaffā. Al-Qāhira: Maktabat al-Šabāb.

Reckendorf H. 1921. Arabische Syntax. Heidelberg: Winter.

Ryding Karin C. 2005. A Reference Grammar of Modern Standard Arabic. Cambridge: Cambridge University Press.

Schulz Eckehard; Krahl Günther; Reuschel Wolfgang. 2000 [1996]. Lehrbuch des modernen Arabisch . Berlin-München: Langenscheidt; revised English edition by Eckehard Schulz. Standard Arabic: An Elementary-Intermediate Course. Cambridge: Cambridge University Press.

Wright W. 1962 [1862]. A Grammar of the Arabic Language. Cambridge: The University Press, 2 vols.

Website addresses [All websites accessed on 31 Jan 2017]:

I http://archive.aawsat.com/details.asp?issueno=8800\&article=195656\#.WJ48nvnhDDc

II he http://daharchives.alhayat.com/issue_archive/Hayat\%20INT/2002/3/19/-معهد_العالم_العربي-يحيب-ربيع-الثعر

html عربياً-وفرنسياً: html/dal

III http://archive.aawsat.com/details.asp?section=4\&article=460527\&issueno=10684\#.VW1SK8_tlNM

IV http://www.dostor.org/282501

v http://www.alhayat.com/Articles/19277768/طلاق-سر اح-Y • _معتقلاً_سياسياً_في_السودان 


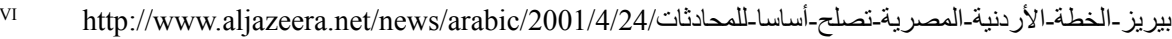

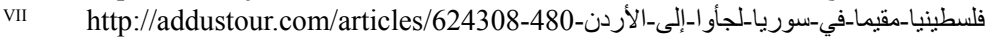

VIII http://www.almasryalyoum.com/news/details/652027

IX http://www.almasryalyoum.com/news/details/657975

x http://arabic.cnn.com/middleeast/2016/01/03/saad-hariri-hassan-nasrallah-iran-saudi-execution

XI http://www.dostor.org/282501

XII https://www.annahar.com/article/37723-تصريف_اعمال:-وزارات_مفتوحة_علي-حساب-وزراء

XIII http://www.alhayat.com/Articles/19885558

XIV http://www.alhayat.com/Articles/17696503

XV http://www.alriyadh.com/169197

XVI http://www.almustaqbal.com/v4/Article.aspx?Type=np\&Articleid=124552

XVII http://www.aljazeera.net/news/international/2009/7/29/استمر ار -الأزمة_الداخلية-بإيران

XVIII http://gate.ahram.org.eg/News/576317.aspx

XIX http://today.almasryalyoum.com/article2.aspx?ArticleID=374603\&IssueID=2803

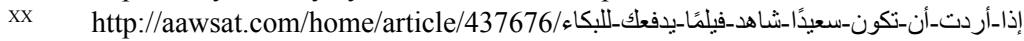

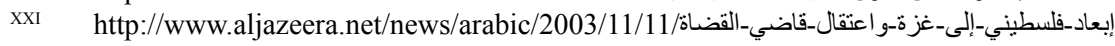

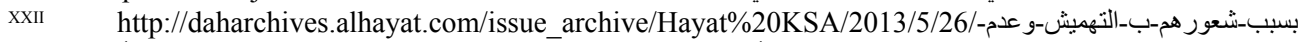

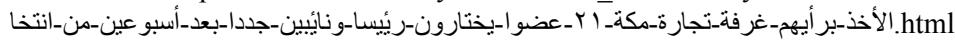

XXIII http://www.alriyadh.com/863151

xxIV http://www.al-jazirah.com/2012/20120105/rj4.htm

xxv http://archive.aawsat.com/details.asp?section=21\&article=706128\&issueno=12418\#.V-2FJfmLTGg

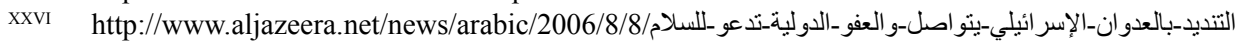

XxVII http://archive.tishreen.news.sy/tishreen/public/read/316011

XXVIII http://www.aljazeera.net/news/arabic/2005/11/24/ششرفة_على_انتخابات_مصر_تتحدث_عن-تزوير-لصالح_الوطني

Xxix http://archive.aawsat.com/details.asp?section=4\&article=655141\&issueno=12075\#.WJDnmlPhDGg

xxx http://www.dostor.org/129034

XXXI http://archive.arabic.cnn.com/2013/entertainment/10/2/celebrities.art.scene.in.a.week/

XxxII http://www.bbc.co.uk/arabic/worldnews/2011/05/110520_somali_pirates_quest.shtml

XXXIII http://archive.aawsat.com/details.asp?section $=4 \&$ article $=251947 \&$ issueno $=9402$

XXXIV http://www.al-jazirah.com/2009/20090701/fe22.htm

xxxv http://www.ahram.org.eg/Archive/1998/10/15/ARAB3.HTM

XXXvI http://classic.aawsat.com/details.asp?article=34262\&issueno=8168\#.VEpQjfmsWTM

XXXVII http://archive.aawsat.com/details.asp?section=4\&article=290906\&issueno=9619\#.VQnAPo6G-TM

xxxvIII http://gate.ahram.org.eg/News/580835.aspx

XXXIX http://classic.aawsat.com/details.asp?section=4\&article=243567\&issueno=9353\#.VEoEV_msWTM

xL http://www.ahram.org.eg/Archive/2003/4/13/Worl4.htm 